\title{
Acaricidal Activity of Crude Ethanolic Extract of Sphaeranthus indicus, its Fractions and Subfractions against Rhipicephalus (Boophilus) annulatus (Acari: Ixodidae)
}

\author{
Thirumangalath Meethal Divya ${ }^{1}$, Valliparampil Chandran Soorya ${ }^{2}$, \\ Krishnan Kavillimakkil Amithamol ${ }^{2}$, Darsana Udayan ${ }^{1}$, Kanapadinchareveetil \\ Sreelekha ${ }^{1}$, Suresh Narayanan Nair ${ }^{1}$, Karaparrambil Gopalan Ajithkumar ${ }^{2}$, \\ Sanis Juliet ${ }^{1}$, Reghu Ravindran ${ }^{2 *}$ and Srikant Ghosh $^{3}$
}

${ }^{1}$ Department of Veterinary Pharmacology and Toxicology, College of Veterinary and Animal Sciences, Kerala Veterinary and Animal Sciences University, Pookode, Lakkidi, P.O., Wayanad, Kerala 673 567, India

${ }^{2}$ Department of Veterinary Parasitology, College of Veterinary and Animal Sciences, Kerala Veterinary and Animal Sciences University, Pookode, Lakkidi, P.O., Wayanad, Kerala 673 567, India

${ }^{3}$ Division of Parasitology, Indian Veterinary Research Institute, Izatnagar, U.P. 243122, India

*Corresponding author

Keywords

Acaricidal effects. Rhipicephalus (Boophilus) annulatus. Sphaeranthus indicus. Ethanolic extract. Fractions, Adult immersion test

Article Info

Accepted: 07 July 2019 Available Online: 10 August 2019
Plants constitute a rich source of bioactive compounds and its acaricidal effect is increasingly been investigated as a potential solution against acaricide resistance. In the present study, the in vitro efficacy of crude ethanolic extract of leaves of Sphaeranthus indicus, its fractions (hexane, chloroform, butanol and water) and subfractions of the active acaricidal fraction were evaluated against Rhipicephalus (Boophilus) annulatus using the adult immersion technique (AIT). The percentage of adult mortality, inhibition of fecundity and hatching rate were assessed. The crude ethanolic extract of leaves of Sphaeranthus indicus revealed hundred per cent adult mortality and inhibition of fecundity at a concentration of $250 \mathrm{mg} / \mathrm{mL}$. Among the four fractions of this extract tested, hexane fraction showed concentration dependent delayed adult tick mortality. At 10 per cent concentration of hexane fraction, 87.41 per cent mortality and 77.78 per cent inhibition of fecundity were observed. Among the 14 subfractions of the active hexane fraction, the subfraction 4 (at $2000 \mathrm{ppm}$ ) produced 45.83 per cent mortality and 41.06 per cent inhibition of fecundity. It may be concluded that the hexane fraction of the leaves of ethanolic extract of $S$. indicus and its subfraction 4 revealed significant acaricidal effects. 


\section{Introduction}

Ticks and tick borne diseases are major constraints for livestock farming in many developing countries. Their impact as disease vectors for human diseases is second to that of mosquitoes and their effect on livestock, wildlife and domestic animals is immeasurably greater (Jongejan and Uilenberg, 2004).

Prospects for control of ticks based on chemical acaricides are limited owing to the development of acaricide resistant ticks as well as public health concerns due to residues in meat and milk. Intensive use of chemical acaricides interferes with enzootic stability, rendering animals susceptible to the diseases (Shkap et al., 2007).

Currently, 904 valid tick species are listed throughout the world (Burger et al., 2014) while 106 species reported from India (Geevarghese et al., 1997). Rhipicephalus (Boophilus) microplus, $R$. sanguineus and Hyalomma anatolicum were reported from many states of India (Ghosh and Nagar, 2014). $R$. (B.) annulatus is reported as the commonest species in southern India (Jagannath et al., 1979; Koshy et al., 1982; Rajamohanan, 1982). Some of the future strategies laid down for the sustainable tick control involves development of vaccines, newer generation chemical acaricides, herbal acaricides and transgenic animals (Ghosh et al., 2007). Plants constitute a rich source of bioactive compounds such as phenolics, terpenoids, coumarins and alkaloids (Ahn et al., 1998) which may possess insecticidal, growth inhibiting, anti-molting and repellent activities (Ghosh et al., 2007). The acaricidal effect of plant products is increasingly been investigated as a potential solution against acaricide resistance (Adenubi et al., 2018). Previously, few plants with acaricidal activity were reported from our laboratory based on their ability to kill the ticks, inhibit their fecundity as well as blocking hatching of the laid ova (Ravindran et al., 2011, 2012, 2015; Juliet et al., 2012; Sunil et al., 2013; Divya et al., 2014; Krishna et al., 2014; Ajeesh et al., 2016; Nair et al., 2017)

Sphaeranthus indicus (commonly known as Gorakhmundi in Hindi, Adakyamaniyan in Malayalam) belongs to the family Asteraceae, is an annual spreading herb, which grows approximately $15-30 \mathrm{~cm}$ in height. The plant is distributed throughout the plains and wet lands in India, Sri Lanka and Australia (Gogate, 2000).

Used traditionally for the treatment of jaundice, leprosy, fever, pectoralgia, cough, gastropathy, hernia, harmorrhoids, helminthiasis, dyspepsia, skin diseases and as a nerve tonic, the plant is known to possess varied medicinal properties and is reportedly used in Ayurvedic preparations for treating epileptic convulsions, mental illness and hemicranias (Ambavade et al., 2006; Jha et al., 2010). The external application of a paste of this herb is claimed beneficial in treating pruritus, edema, arthritis, filariasis, gout and cervical adenopathy (Paranjape, 2001).

Pharmacological activities such as immunomodulatory (Bafna and Mishra, 2006), antimicrobial (Singh et al., 1988; Duraipandiyan et al., 2009), anxiolytic (Ambavade et al., 2006), wound healing (Sadaf et al., 2006; Jha et al., 2009), antioxidant (Shriwaikar et al., 2006; Prabhu et al., 2009), hepatoprotective (Tiwari and Khosa, 2010) and anti-inflammatory activities (Nanda et al., 2010) were reported for this plant. The acaricidal activity of the plant was previously not reported. Hence, the present study aims at studying the acaricidal activity of crude ethanolic extract of $S$. indicus, its different fractions and subfractions against adult female $R$. (B.) annulatus ticks. 


\section{Materials and Methods}

\section{Ticks}

Fully engorged adult female ticks apparently of the same size were collected randomly from the infested calves. These animals were not treated with any acaricides for 60 days prior to the collection of ticks. The ticks were washed in tap water and mopped dry using an absorbent paper.

\section{Plant materials}

The plant was collected from Wayanad district of Kerala in May 2011. It was identified by a botanist and voucher specimen was deposited at Calicut University Herbarium (Accession number, CALI: 6635), Calicut, Kerala.

\section{Preparation of ethanolic crude extract}

One kilogram of dried leaves of the plant was pulverized. A portion of the powdered material (120g) was used for ethanolic extraction in a soxhlet apparatus attached with a solvent recovery unit (Rotavac, Buchi, Switzerland). The crude extract produced was then dried at room temperature, weighed and dissolved in methanol to prepare different concentrations of extract $(50 \mathrm{mg} / \mathrm{mL}$, $100 \mathrm{mg} / \mathrm{mL}$ and $250 \mathrm{mg} / \mathrm{mL}$ ) for testing the acaricidal activity.

\section{Preparation of extract, fractions and subfractions}

The crude ethanolic extract was fractionated using solvents of ascending polarity such as hexane, chloroform, n-butanol and water. The crude extract $(200 \mathrm{~g})$ was transferred to a separating funnel and extracted with hexane to obtain the hexane soluble fraction. Then, the hexane insoluble fraction was extracted with chloroform to yield chloroform soluble fraction. Further, the chloroform insoluble fraction was extracted with n-butanol and subsequently with water to yield n-butanol soluble and aqueous fractions. Solvents were removed using Rotavac unit and dried at room temperature and used for testing the acaricidal activity and phytochemical screening.

\section{Thin layer chromatography}

Thin layer chromatography was performed to find out the exact solvent system for column chromatography. Composition of each active fraction was assessed by one way ascending thin layer chromatography on silica gel precoated aluminium paper plates with thickness of $0.25 \mathrm{~mm}$ (Merck F245). The sample $(1 \mathrm{mg})$ was applied to a plate, about $1 \mathrm{~cm}$ from the base. The plate was then dipped into a chamber containing fixed combination of solvent system and placed in a sealed container. Different subfractions in the sample mixture moved at different rates due to differences in solubility in the solvent and due to differences in their attraction to the stationary phase. Mobile phase of different compositions were tried and the solvent system with maximum efficient separation of subcomponent was selected as the solvent system for column chromatographic separation. Plates were visualized under 254 $\mathrm{nm}$ and $365 \mathrm{~nm}$ UV light (Ultraviolet Radiation Obligatory eye protection: Vilber Lourmat serial No V01 5636).

\section{Column Chromatography}

Silica gel (100 - 200 mesh, 200g, Merck), activated at $80^{\circ} \mathrm{C}$ for 1 hour and $5 \mathrm{~g}$ of respective active fraction was packed in $3 \times 60$ $\mathrm{cm}$ glass column and eluted with suitable solvent system, chloroform: hexane (80:20) for the active hexane fraction and hexane: chloroform (80:20) for subfraction identified in TLC for separation. Packing of the column was done in low polarity solvents such as hexane and the flow rate was adjusted to 1-3 
drops per minute. Subfractions eluted from the active fraction were collected in separate glass tubes. Each subfraction was concentrated by removing the solvents in rotary vacuum evaporator and used for testing acaricidal properties.

\section{High performance thin layer chromatography (HPTLC)}

Chromatographic separation using HPTLC analysis (Camag, Switzerland) was performed on Merck TLC plates precoated with silica gel 60 F254 $(20 \mathrm{~cm} \times 10 \mathrm{~cm}$ with $200 \mu \mathrm{m}$ layer thickness) from E. Merck, Germany. Sample solution $(0.5 \mu \mathrm{L}$ and $3 \mu \mathrm{L})$ was applied onto the plates as a band with $8 \mathrm{~mm}$ width using Camag 100 microlitre sample syringe (Hamilton, Switzerland) with a Camag Linomat 5 applicator (Camag, Switzerland). Linear ascending development was carried out in a twin trough glass chamber $(20 \times 10 \mathrm{~cm})$ with the mobile phase chloroform: hexane (80:20) for hexane fraction and hexane: chloroform (80:20) for active subfraction. Scanning was performed using Camag TLC scanner 3 at $254 \mathrm{~nm}, \quad 366 \mathrm{~nm}$ and $550 \mathrm{~nm}$ through fluorescence mode and operated by win CATS software (version 1.4.1, Camag). Plates are visualized under UV 254nm, UV 366nm and in visible light after derivatizing with Anisaldehyde - sulfuric acid (ANS) reagent.

\section{Phytochemical analysis}

The active fraction was subjected to phytochemical tests for plant secondary metabolites like tannins, saponins, steroid, alkaloids and glycosides in accordance with Harbone (1991).

\section{Adult immersion test (AIT)}

Adult immersion test (AIT) was performed based on the method previously described Drummond et al., (1973). Deltamethrin at a concentration of $0.03 \mathrm{mg} / \mathrm{mL}$ was used as positive control and methanol as negative control. A total of 24 ticks were used for each dilution with four replicates of six ticks. Ticks were weighed prior to the experiment and were immersed for 2 minutes in the respective dilution $(10 \mathrm{~mL})$ in a $50 \mathrm{~mL}$ beaker with gentle agitations. Ticks were recovered from the solution, dried using tissue paper towels and placed in separate plastic specimen tubes $(25 \mathrm{x}$ $50 \mathrm{~mm})$. The tubes were incubated at $28 \pm 2{ }^{\circ} \mathrm{C}$ and $80 \%$ relative humidity in a BOD incubator. These ticks were observed for oviposition and mortality for 15 days. Mortality of the adult tick and weight of the eggs laid by the treated ticks were recorded in comparison with the control. The eggs laid by the ticks in each replicates were collected, weighed and observed at the same condition of incubation for the next 30 days for visual estimation of hatching. Ticks under different treatments were compared with that of the controls. Adult tick mortality, percent inhibition of fecundity and hatching of laid eggs by treated ticks were evaluated FAO (2004).

\section{Adult tick mortality}

The number of dead ticks in the specimen tubes was observed within 15 days after incubation. The percentage of adult tick mortality was then determined.

\section{Inhibition of fecundity and hatching}

The eggs laid by ticks in each tube were collected, weighed and observed at the same conditions of incubation for the next 30 days for visual estimation of hatching. Ticks under different treatments were compared with that of controls.

The percentage inhibition of fecundity was calculated as follows: 
Index of egg laying (IE) = weight of eggs laid (mg) / weight of females (mg)

Percentage inhibition of fecundity (IF) $=[$ IE (control group) -IE (treated group)] x 100 / IE (control group).

\section{Statistical analysis}

Statistical analysis of data was performed using standard procedures of Snedecor and Cochran (1994). Data were expressed as the mean \pm SEM. Groups were compared using one-way ANOVA for repeated measurements using SPSS software. Duncan's test was used for post-hoc analysis. A value of $\mathrm{P}<0.05$ was considered significant.

\section{Results and Discussion}

The efficacy of crude ethanolic extract of leaves of $S$. indicus against female $R$. (B.) annulatus is presented in table 1. Mortality of the adult ticks increased with increasing concentrations of the extract. A statistically significant effect on adult mortality could be observed at higher concentrations of 100 $\mathrm{mg} / \mathrm{mL}$ and $250 \mathrm{mg} / \mathrm{mL}$ compared to vehicle control (methanol) and deltamethrin. The inhibition of fecundity ranged from 36.47 (at $50 \mathrm{mg} / \mathrm{mL}$ ) to 100 per cent (at $250 \mathrm{mg} / \mathrm{mL}$ ) on the treated ticks.

The per cent extractive values of hexane, chloroform, n-butanol and aqueous fractions of $S$. indicus are 16, 7, 2 and 5.75 respectively. Significant acaricidal activity against $R$. (B.) annulatus was observed only with hexane fraction of the crude ethanolic extract of leaves of $S$. indicus in comparison to other fractions. The per cent adult tick mortality caused by hexane fraction varied from 49.99 to 87.49 per cent when tested at concentrations ranging from 25 to $100 \mathrm{mg} / \mathrm{mL}$ (Table 2). Mortality was mainly seen after 7 days of treatment. The inhibition of fecundity varied from 36.21 to 77.78 per cent. The per cent mortality and inhibition of fecundity were concentration dependent. The hexane fraction did not exert any effect on the hatching of eggs laid by the treated ticks. The n-butanol fraction though exhibited some dose dependent effect on tick mortality and inhibition of fecundity; it was not significant compared to the hexane fraction. The chloroform and aqueous fractions did not exhibit any effect on adult tick mortality or inhibition of fecundity.

The hatching of the eggs laid by the ticks treated with n-butanol, chloroform and water fractions was apparently normal compared to control.

The acaricidal hexane fraction was further analyzed to ascertain the most effective subfraction. Suitable solvent system comprising chloroform: hexane (80:20) was identified based on TLC and HPTLC finger print profiles (Fig. 1). Fourteen subfractions were separated from hexane fraction by column chromatography with chloroform: hexane (80:20) as mobile phase. The acaricidal hexane fraction of $S$. indicus gave positive result for alkaloids, tannins and flavonoids.

The results of adult immersion test of fourteen subfractions of the active hexane fraction of crude ethanloic extract of leaves of $S$. indicus against $R$. (B.) annulatus are presented in table 3. Among fourteen subfractions, sub-fractions 2, 3, 4, 6 and 10 exhibited toxic effect on ticks. The subfraction 4 recorded the highest mortality (at 2000ppm concentration) of treated ticks.

The per cent mortality and inhibition of fecundity for active subfraction 4 were 45.83 and 41.06 per cent respectively. None of the subfractions significantly affected egg hatchability. 
Fig.1 HPTLC finger print profile of hexane fraction of ethanolic extract of leaves of $S$. indicus at wavelength 366 nm eluted with Chloroform: Hexane (80:20)
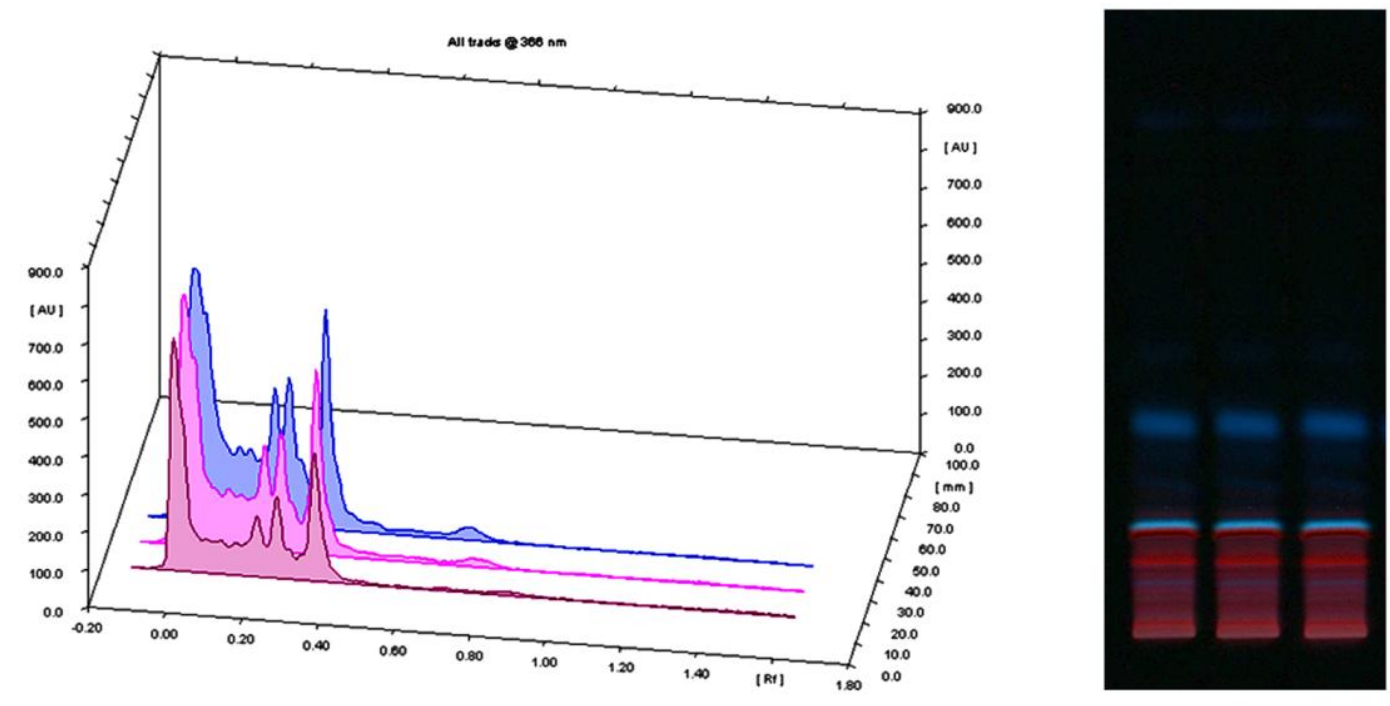

Table.1 Acaricidal effects of crude ethanolic extract of leaves of $S$. indicus against R. (B.) annulatus

\begin{tabular}{|c|c|c|c|c|c|c|c|}
\hline $\begin{array}{c}\text { S1. } \\
\text { No }\end{array}$ & $\begin{array}{c}\text { Concentration } \\
\mathrm{mg} / \mathrm{ml}\end{array}$ & $\begin{array}{c}\text { Mean ticks weight } \\
\text { per replicate } \pm \\
\text { SEM } \\
(\mathrm{g})\end{array}$ & $\begin{array}{c}\text { Mean \% adult } \\
\text { mortality within } \\
15 \text { days } \pm \text { SEM }\end{array}$ & $\begin{array}{c}\text { Mean eggs } \\
\text { mass per } \\
\text { replicate } \\
\text { SEM } \\
(\mathrm{g})\end{array}$ & $\begin{array}{c}\text { Index of } \\
\text { fecundity } \pm \\
\text { SEM }\end{array}$ & $\begin{array}{c}\text { Percentage } \\
\text { Inhibition } \\
\text { of } \\
\text { Fecundity } \\
(\%)\end{array}$ & $\begin{array}{c}\text { Hatching } \\
\text { (Visual) }\end{array}$ \\
\hline 1. & Methanol & $1.0182 \pm 0.0382^{\mathrm{bc}}$ & $0 \pm 0^{\mathrm{a}}$ & $0.4381 \pm 0.0300^{\mathrm{d}}$ & $0.4299 \pm 0.0240^{\mathrm{c}}$ & 0 \\
\hline 2. & 50 & $1.0824 \pm 0.0373^{\mathrm{c}}$ & $\begin{array}{c}20.8275 \\
\pm 4.1675^{\mathrm{b}}\end{array}$ & $0.2969 \pm 0.0366^{\mathrm{c}}$ & $0.2731 \pm 0.0282^{\mathrm{bc}}$ & 36.47 & 100 \\
\hline 3. & 100 & $0.5525 \pm 0.0135^{\mathrm{a}}$ & $41.665 \pm 4.812^{\mathrm{c}}$ & $0.1242 \pm 0.0733^{\mathrm{b}}$ & $0.2269 \pm 0.0132^{\mathrm{b}}$ & 47.22 & 100 \\
\hline 4. & 250 & $0.9699 \pm 0.0369^{\mathrm{b}}$ & $100 \pm 0^{\mathrm{d}}$ & $0 \pm 0^{\mathrm{a}}$ & $0 \pm 00^{\mathrm{a}}$ & 100 \\
\hline 5 & $\begin{array}{c}\text { Deltamethrin } \\
0.03\end{array}$ & $0.9653 \pm 0.0361^{\mathrm{b}}$ & $16.662 \pm 6.803^{\mathrm{b}}$ & $\begin{array}{c}0.2081 \\
\pm 0.0276^{\mathrm{bc}}\end{array}$ & $0.2140 \pm 0.0236^{\mathrm{b}}$ & 57.3 & 10 \\
\hline
\end{tabular}

$\mathrm{n}=4$, Values are Mean $\pm \mathrm{SEM}$, means bearing different superscripts $\mathrm{a}, \mathrm{b}, \mathrm{c}, \mathrm{d}(\mathrm{P}<0.05)$, indicate significant difference when compared with the control and recommended concentration of deltamethrin. 
Table.2 Acaricidal effects of hexane fraction extracted from the ethanolic extract of leaves of $S$. indicus against $R$. (B.) annulates

\begin{tabular}{|c|c|c|c|c|c|c|c|}
\hline $\begin{array}{c}\text { Sl. } \\
\text { No }\end{array}$ & $\begin{array}{c}\text { Concentration } \\
\mathrm{mg} / \mathrm{ml}\end{array}$ & $\begin{array}{c}\text { Mean ticks } \\
\text { weight per } \\
\text { replicate } \pm \text { SEM } \\
(\mathrm{g})\end{array}$ & $\begin{array}{c}\text { Mean \% adult } \\
\text { mortality within } \\
15 \text { days } \pm \text { SEM }\end{array}$ & $\begin{array}{c}\text { Mean eggs mass } \\
\text { per replicate } \pm \\
\text { SEM (g) }\end{array}$ & $\begin{array}{c}\text { Index of } \\
\text { fecundity } \pm \text { SEM }\end{array}$ & $\begin{array}{c}\text { Percentage } \\
\text { Inhibition } \\
\text { of } \\
\text { Fecundity } \\
(\%)\end{array}$ & $\begin{array}{c}\text { Hatching } \\
\text { (Visual) }\end{array}$ \\
\hline 1. & Methanol & $0.8885 \pm 0.0308^{\mathrm{ab}}$ & $0^{\mathrm{ab}}$ & & & \\
\hline 2. & 25 & $0.8264 \pm 0.0247^{\mathrm{a}}$ & $49.997 \pm 6.8035^{\mathrm{b}}$ & $0.2152 \pm 0.0219^{\mathrm{b}}$ & $0.2618 \pm 0.0306^{\mathrm{b}}$ & 36.21 & 100 \\
\hline 3. & 50 & $0.8034 \pm 0.0270^{\mathrm{a}}$ & $58.330 \pm 10.757^{\mathrm{b}}$ & $0.1776 \pm 0.0386^{\mathrm{b}}$ & $0.2212 \pm 0.05051^{\mathrm{b}}$ & 46.10 & 100 \\
\hline 4. & 100 & $0.7910 \pm 0.0595^{\mathrm{a}}$ & $87.4975 \pm 4.1675^{\mathrm{c}}$ & $0.0069 \pm 0.0096^{\mathrm{a}}$ & $0.0912 \pm 0.0165^{\mathrm{a}}$ & 77.78 & 100 \\
\hline 5 & $\begin{array}{c}\text { Deltamethrin } \\
0.03\end{array}$ & $0.9653 \pm 0.0361^{\mathrm{b}}$ & $16.662 \pm 6.803^{\mathrm{a}}$ & $0.2081 \pm 0.0276^{\mathrm{b}}$ & $0.2140 \pm 0.0236^{\mathrm{b}}$ & 57.3 & 10 \\
\hline
\end{tabular}

$\mathrm{n}=4$, Values are Mean \pm SEM, means bearing different superscripts $\mathrm{a}, \mathrm{b}, \mathrm{c}, \mathrm{d}(\mathrm{P}<0.05)$, indicate significant difference when compared with the control and recommended concentration of deltamethrin.

Table.3 Acaricidal effects of sub-fractions obtained from the active hexane fraction of $S$. indicus against $R$. (B.) annulatus at 2000ppm

\begin{tabular}{|c|c|c|c|c|c|c|c|}
\hline $\begin{array}{l}\text { Sl. } \\
\text { No }\end{array}$ & $\begin{array}{c}\text { Concentration } \\
\mu \mathrm{g} / \mathrm{ml}\end{array}$ & $\begin{array}{c}\text { Mean ticks } \\
\text { weight per } \\
\text { replicate } \pm \text { SEM } \\
(\mathrm{g})\end{array}$ & $\begin{array}{l}\text { Mean } \% \text { adult } \\
\text { mortality } \\
\text { within } 15 \text { days } \\
\pm \text { SEM }\end{array}$ & $\begin{array}{c}\text { Mean eggs mass } \\
\text { per replicate } \pm \\
\text { SEM } \\
\text { (g) }\end{array}$ & $\begin{array}{c}\text { Index of } \\
\text { fecundity } \pm \\
\text { SEM }\end{array}$ & $\begin{array}{l}\text { Percentage } \\
\text { Inhibition } \\
\text { of } \\
\text { Fecundity } \\
(\%)\end{array}$ & $\begin{array}{c}\text { Hatching } \\
\% \\
\text { (Visual) }\end{array}$ \\
\hline 1. & Methanol & $0.6624 \pm 0.0240^{\mathrm{ab}}$ & $0 \pm 0^{\mathrm{a}}$ & $0.4400 \pm 0.0310^{\mathrm{e}}$ & $0.6712 \pm 0.0659^{d}$ & 0 & 100 \\
\hline 2. & Subfraction 1 & $0.6163 \pm 0.0280^{\mathrm{a}}$ & $0 \pm 0^{\mathrm{a}}$ & $0.3101 \pm 0.0062^{\mathrm{bc}}$ & $0.5063 \pm 0.0243^{c}$ & & 100 \\
\hline 3. & Subfraction2 & $0.6546 \pm 0.0219^{\mathrm{ab}}$ & $12.497 \pm 7.977^{\mathrm{a}}$ & $0.337 \pm 0.0108^{c}$ & $0.5124 \pm 0.0300^{c}$ & & 100 \\
\hline 4. & Subfraction3 & $0.7671 \pm 0.0330^{c}$ & $4.1650 \pm 0.0416^{\mathrm{a}}$ & $0.4091 \pm 0.0307^{\mathrm{de}}$ & $0.5311 \pm 0.0203^{c}$ & 7 & 100 \\
\hline 5. & Subfraction4 & $0.6748 \pm 0.0348^{\mathrm{ab}}$ & $45.830 \pm 14.235^{\mathrm{b}}$ & $0.2643 \pm 0.0100^{b}$ & $0.3956 \pm 0.0279^{b}$ & 41.06 & 100 \\
\hline 6. & Subfraction5 & $0.6748 \pm 0.0348^{\mathrm{ab}}$ & $0 \pm 0^{\mathrm{a}}$ & $0.3355 \pm 0.0110^{c}$ & $0.4978 \pm 0.0270^{c}$ & 25.83 & 100 \\
\hline 7 & Subfraction6 & $0.7005 \pm 0.0116^{\mathrm{abc}}$ & $\begin{array}{l}12.497 \pm \\
7.9775^{\mathrm{a}}\end{array}$ & $0.3551 \pm 0.0251^{\text {cd }}$ & $0.5063 \pm 0.0306^{c}$ & 24.57 & 100 \\
\hline 8 & Subfraction7 & $0.6270 \pm 0.0348^{\mathrm{ab}}$ & $0 \pm 0^{\mathrm{a}}$ & $0.3156 \pm 0.0210^{b c}$ & $0.5104 \pm 0.0508^{c}$ & 23.96 & 100 \\
\hline 9 & Subfraction8 & $0.6567 \pm 0.0216^{\mathrm{ab}}$ & $0 \pm 0^{\mathrm{a}}$ & $0.3414 \pm 0.0070^{c}$ & $0.5209 \pm 0.0140^{c}$ & 22.39 & 100 \\
\hline 10 & Subfraction 9 & $0.6892 \pm 0.0286^{\mathrm{abc}}$ & $0 \pm 0^{\mathrm{a}}$ & $0.3517 \pm 0.0195^{\mathrm{cd}}$ & $0.5111 \pm 0.0266^{c}$ & 23.85 & 100 \\
\hline 11 & Subfraction 10 & $0.6552 \pm 0.0261^{\mathrm{ab}}$ & $4.1650 \pm 4.1650^{\mathrm{a}}$ & $0.3328 \pm 0.0105^{c}$ & $0.5107 \pm 0.0288^{c}$ & 23.91 & 100 \\
\hline 12 & Subfraction 11 & $0.6734 \pm 0.0090^{\mathrm{ab}}$ & $0 \pm 0^{\mathrm{a}}$ & $0.3431 \pm 0.0158^{c}$ & $0.5101 \pm 0.0265^{\mathrm{c}}$ & 24.00 & 100 \\
\hline 13 & Subfraction 12 & $0.6734 \pm 0.0090^{\mathrm{ab}}$ & $0 \pm 0^{\mathrm{a}}$ & $0.3370 \pm 0.0220^{c}$ & $0.5008 \pm 0.0329^{c}$ & 25.39 & 100 \\
\hline 14 & Subfraction 13 & $0.6878 \pm 0.0067^{\mathrm{abc}}$ & $0 \pm 0^{\mathrm{a}}$ & $0.3521 \pm 0.0150^{\text {cd }}$ & $0.5120 \pm 0.0213^{c}$ & 23.72 & 100 \\
\hline 15 & Subfraction 14 & $0.7112 \pm 0.0168^{\mathrm{bc}}$ & $0 \pm 0^{\mathrm{a}}$ & $0.3605 \pm 0.0232^{\text {cd }}$ & $0.5077 \pm 0.349^{c}$ & 24.36 & 100 \\
\hline 16 & Deltamethrin(30) & $0.9653 \pm 0.0361^{\mathrm{d}}$ & $16.6625 \pm 6.803^{\mathrm{a}}$ & $0.2081 \pm 0.0276^{a}$ & $0.2140 \pm 0.0236^{a}$ & 57.3 & 10 \\
\hline
\end{tabular}

$\mathrm{n}=4$, Values are Mean \pm SEM, means bearing different superscripts $\mathrm{a}, \mathrm{b}, \mathrm{c}(\mathrm{P}<0.05)$, indicate significant difference when compared with the control and recommended concentration of deltamethrin. 
In the present study, crude ethanolic extract of $S$. indicus demonstrated a significant concentration dependent effect on adult mortality and inhibition of fecundity. Qualitative phytochemical analysis of the acaricidal hexane fraction of the extract detected the presence of tannins, flavonoids and alkaloids. Subfraction 4 of hexane fraction of crude ethanolic extract of $S$. indicus showed the acaricidal activity.

Previous reports on $S$. indicus revealed that the aerial part of the plant is quite rich in flavonoids, essential oils, glycosides and eudesmanolides along with some uncharacterized sesquiterpenes, phenolic glycosides and sesquiterpene lactones (Galani and Patel, 2009). Besides, C-glycoside, 5hydroxy-7-methoxy-6-C-glycosylflavone, npentacosan, sterols, stigmasterol, $\beta$-sitosterol, hentriacontane, $\quad \beta$-D-glucoside $\quad$ of hentriacontane, n-triacontanol, sphaeranthine, isoflavone, 5, 4-dimethoxy-3-prenylbiochanin 7-O- $\beta$-galactoside (Jadhav et al., 2007; Mishra et al., 2007; Tiwari and Khosa, 2010) were also isolated from this herb. Biologically active compounds such as eudesmanolides (Shekhani et al., 1991), methyl chavicol, $\alpha$ ionone, $\delta$-cadinene, $\mathrm{p}$ methoxycinnamaldehyde, thymoquinoldimethyl ether, pdephene- 2 and T-cadnol (Kaul et al., 2005), ocimene, $\alpha$-terpinene, methyl chavicol, $\alpha$ - citral, geraniol, $\alpha$-ionone, $\beta$-ionone, $\delta$-cadinene, $\quad \mathrm{p}$-methoxy cinnamaldehyde, sphaeranthine, stigmasterol, $\beta$ sitosterol, hentriacontane, sesquiterpene lactone, sesquiterpene glycoside, sphaeranthanolides, flavones, isoflavone glycoside (Ambavade et al., 2006) were also isolated from the whole plant of $S$. indicus. Sesquiterpene alkaloids isolated from $S$. indicus exhibited strong deterrent activity against several insects (Liu et al., 1990). Sesquiterpene lactones were also shown to provide resistance to insect feeding (Burnett et al., 1974). Previously different extracts of the plant revealed insecticidal activities against Callosobruchus chinensis (Baby, 1994), Tribolium castaneum (Tiwari and Saxena, 2003), Sitotroga cerealella (Srinivasan and Nadarajan, 2006), S. indicus also exhibited larvicidal effect against mosquitoes (Arivoli et al., 2016).

It can be concluded that, the hexane fraction of the ethanolic extract of $S$. indicus and its subfraction 4 have significant acaricidal effects. Further, analysis of the subfraction 4 by GC MS will detect the phytochemical compound responsible for the activity.

\section{Acknowledgments}

Financial supports from Indian Council of Agricultural Research (ICAR) through research projects (NFBSFARA/BSA4004/2013-14, NASF/ABA-6015/2016-17, No.7(2)/- 2011- EPD) and National Bank for Agriculture and Rural Development G.O.(Rt)No.100/12/ AD RIDF XVI KERALA) are thankfully acknowledged.

\section{References}

Adenubi O.T., McGaw, L.J., Eloff, J.N. and Naidoo, V. 2018. In vitro bioassays used in evaluating plant extracts for tick repellent and acaricidal properties: A critical review. Veterinary Parasitology, 254, pp 160-171.

Ahn, Y.J., Lee, H. S. and Kim, G.H., 1998. Insecticidal and acaricidal activity of carvacol and $\beta$-thujaplicine derived from Thujopsis dolabrata var. Hondai. Journal of Chemical Ecology, 24, pp. 81-90.

Ajeesh, K.T. P., Adarsh K.T. P., Juliet S., Kumuthakalavalli R., Ramasubbu R., Sunil A., Ravindran R., Leena C., Suresh N. N. and Ghosh S., 2016. Pharmacochemical characterization and acaricidal activity of ethanolic extract of Chassalia curviflora (Wall ex Kurz.) Thwaites. Pharmacognosy Journal, 8, pp. 215-219. 
Ambavade, S.D., Mhetre, N.A., Tate, V.D. and Bodhankar, S.L., 2006. Pharmacological evaluation of the extracts of Sphaeranthus indicus flowers on anxiolytic activity in mice. Indian Journal of Pharmacology, 38, pp. 254-259.

Arivoli, S., Tennyson, S., Raveen, R., Jayakumar, M. Senthilkumar, B., Govindarajan, M., Babujanarthanam, R. and Vijayanand, S. 2016. Larvicidal activity of fractions of Sphaeranthus indicus Linnaeus (Asteraceae) ethyl acetate whole plant extract against Aedes aegypti Linnaeus 1762, Anopheles stephensi Liston 1901 and Culex quinquefasciatus Say 1823 (Diptera: Culicidae) International Journal of Mosquito Research, 3, pp.18-30.

Baby, J.K. 1994. Repellent and phlagodeterrent activity of Sphaeranthus indicus extract against Callosobruchus chinensis. In: Proceedings of the 6th International Working Conference on: Stored-Product Protection, Canberra, Australia, pp.746748.

Bafna, A.R. and Mishra S.H. 2006.Protective effect of bioactive fraction of Sphaeranthus indicus L. against cyclophosphamide induced suppression of humoral immunity in mice. Journal of Ethnopharmacology, 104, pp.426-429.

Burger, T. D., Shao, R., Labruna, M. B. and Barker, S.C. 2014. Molecular phylogeny of soft ticks (Ixodida: Argasidae) inferred from mitochondrial genome and nuclear rRNA sequences. Ticks and Tick Borne Diseases, 5, pp. 195-207.

Burnett, W.C., Jones, S.B., Mabry, T.J. and Padolina, W.G. 1974. Sesquiterpene lactones: insect feeding deterrents in Vernonia. Biochemical Systematics and Ecology, 2, pp. 25-29.

Divya, T.M., Soorya, V.C., Amithamol, K.K., Juliet, S., Ravindran, R., Nair, S.N. and Ajithkumar, K.G. 2014. Acaricidal activity of alkaloid fractions of Leucas indica Spreng against Rhipicephalus (Boophilus) annulatus tick. Tropical Biomedicine, 31, pp. 46-53).
Drummond, R., Ernst, S.E., Trevino, J.L., Gladney, W.J. and Graham O.H. 1973. Boophilus annulatus and Boophilus microplus: laboratory tests for insecticides. Journal of Economic Entomology, 66, pp.130-133.

Duraipandiyan, V., Kannan, P. and Ignacimuthu, S. 2009. Antimicrobial activity of Sphaeranthus indicus L. Ethnobotanical Leaflets, 13, pp. 320-325.

FAO. 2004. Ticks. acaricide resistance: diagnosis management and prevention in: guidelines resistance management and integrated parasite control in ruminants. FAO Animal Production and Health Division, Rome.p.9.

Galani, V.J. and Patel, B.G. 2009. Psychotropic activity of Sphaeranthus indicus Linn. in experimental animals. Pharmacognosy Research, 1, 307-313.

Geevarghese, G., Fernandes, S. and Kulkarni, S.M. 1997. A checklist of Indian ticks (Acari: Ixodidae). Indian Journal of Animal Science, 67, pp. 566-574.

Ghosh, S. and Nagar, G. 2014. Problem of ticks and tick-borne diseases in India with special emphasis on progress in tick control research: A review. Journal of Vector Borne Diseases, 51, pp. 259-270.

Ghosh, S., Azhahianambi, P. and Yadav, M.P. 2007. Upcoming and future strategies of tick control: A review. Journal of Vector Borne Diseases, 44, pp. 79-89.

Gogate, V.M. 2000. Ayurvedic pharmacology and therapeutic uses of medicinal plants (Dravya ganvigyan). Mumbai: Bhartiya Vidya Bhavan pp. 112-114.

Harbone, J.B. 1991. Phytochemical methods: Guide to modern techniques of plant analysis ( $2^{\text {nd }}$ ed.). Chapman and Hall, India. p. 653.

Jadhav, R.B., Sonawane, K.B., Deshpande, N.R., and Rojatkar, S.R. 2007 Two new eudesmanolides from Sphaeranthus indicus Linn. Indian Journal of Chemistry-Section B, 46, 379-381.

Jagannath, M.S., Muraleedharan, K. and Hiregoudar, L.S. 1979. Prevalence of ixodid ticks of cattle at Bangalore. Indian 
Journal of Animal Science. 49, pp. 890894

Jha, R.K., Mangilal, A., Bhandari, K. and Nema, R.K. 2010. Antidiabetic activity of flower head petroleum ether extracts of Sphaeranthus indicus Linn. Asian Journal of Pharmaceutical and Clinical Research, 3, 16-19.

Jha, R.K., Garud, N. and. Nema, R.K. 2009. Excision and incision wound healing activity of flower head alcoholic extract of Sphaeranthus indicus Linn. in Albino rats. Global Journal of Pharmacology, 3, pp. 32-37.

Jongejan, F. and Uilenberg, G. 2004. The global importance of ticks. Parasitology 129, (Supplement): S3-S14

Juliet, S., Ravindran, R., Sunil, A.R., Ajithkumar, K.G., Nair, S.N., Amithamol, K.K., Bandyopadhyay, A., Rawat, A.K.S. and Ghosh, S. 2012. Jatropha curcas (Linn) leaf extract -a possible alternative for population control of Rhipicephalus (Boophilus) annulatus. Asian Pacific Journal of Tropical Disease, 5, pp. 225229.

Kaul, P.N., Bhaskaruni, R.R., Bhattacharya, A.K., Singh, K., Mallavarapu G.R. and Ramesh S. 2005. Essential oil composition of Sphaeranthus indicus L. Journal of Essential Oil Research, 17, pp. 453-454.

Koshy, T.J., Rajavelu, G. and Lalitha, C.M. 1982. Ecology and bionomics of Boophids of Tamil Nadu. Cheiron, 11, 25-30.

Krishna, T.P.A., Ajeesh, K.T.P., Chitra, N.D., Deepa, P.E., Udayan, D., Sreelekha, K.P., Juliet, S., Nair, S.N., Ravindran, R., Ajithkumar K.G. and Ghosh S. 2014. Acaricidal activity of petroleum ether extract of Tetrastigma leucostaphylum (Dennst.) Alston against Rhipicephalus (Boophilus) annulatus. Scientific World J. Article ID: 715481, http://dx.doi.org/10.1155/2014/715481.

Liu, J.K., Z.J. Jia, Wu, D.G., Zhou, J. and Wang, Q.G. 1990. Insect antifeeding agents: sesquiterpene alkaloids from
Celastrus angulatus. Phytochemistry, 29, pp. 2503-2506.

Mishra, B.B., Yadav, S.B., Singh, R.K. and Tripathi, V. 2007. A novel flavanoid Cglycoside from $S$ indicus L. Molecules, 12, pp. 2288-2291

Nair. N. S., Juliet S., Amithamol K. K., Sunil A R, Adarsh K.T. P., Sreelekha K. P., Divya T. M. Darsana U., Ajith Kumar K.G., Ghosh S., and Ravindran R. 2017. In vitro acaricidal effects of ethanolic extract and its fractions of Ageratum conyzoides L. against common cattle tick, Rhipicephalus (Boophilus) annulatus. Annals of Phytomedicine, 6, pp. 162-168.

Nanda, B.K., Jena, J, Rath, B. and Behera, B. 2010. Anti- inflammatory activity of whole parts of Sphaeranthus indicus Linn. Der Pharmacia Lettre, 2, pp. 181188.

Paranjape, P. 2001. Indian medicinal plants. In: Forgotten healer: A guide to Ayurvedic herbalmedicine. Delhi: Chaukhamba Sanskrit Pratisthan, pp.148-149.

Prabhu, K.S., Lobo, R. and Shirwaikar, A. 2009. Free radical scavenging activity of aqueous extract of Sphaeranthus indicus Linn. Pharmacologyonline, 2, pp. 468476.

Rajamohanan, K. 1982. Identification of vector for babesiosis of cattle in Kerala. Proceedings of All India Symposium of vectors and vector borne diseases, Trivandrum, Kerala. 125-128

Ravindran, R., Juliet, S., Sunil, A.R., Ajith Kumar, K.G., Nair, S.N., Amithamol, K.K., Shynu, M., Rawat, A.K.S.and Ghosh, S. 2011. Eclosion blocking effect of extract of Leucas aspera L. on Rhipicephalus (Boophilus) annulatus. Veterinary Parasitology, 179, pp. 287 290.

Ravindran, R., Juliet, S., Sunil, A.R., Ajith Kumar, K.G., Nair, S.N., Amithamol, K.K., Bandyopadhyay, A., Rawat, A.K.S. and Ghosh, S. 2012. Acaricidal activity of Cassia alata against Rhipicephalus (Boophilus) annulatus. Experimental Applied Acarology, 56, pp. 69-74 
Ravindran, R., Chithra, N.D., Deepa, P.E., Juliet, S., Ajithkumar K.G., Nair, S. N., Udayan, D., Nanjundappa, S., Chandrasekhar, L. and Ghosh, S. 2015. Contrasting effects of ethanolic extracts of leaf and flower of Chromolaena odorata against Rhipicephalus (Boophilus) annulates. Indian Journal of Animal Science, 85, 844-848.

Sadaf, F., Saleem, R., Ahmed, M., Ahmad, S.L. and Zafar, N.U. 2006. Healing potential of cream containing extract of S.indicus on dermal wounds in Guinea pig. Journal of Ethnopharmacology, 107, pp. 161-163.

Shekhani, M.S., Shah, P.M., Khan, K.M. and Rahman, A.U. 1991. New eudesmanolide from $S$. indicus. Journal of Natural Products, 54, pp-882-885.

Shkap, V., de Vos, A.J., Zweygarth, E. and Jongejan, F. 2007. Attenuated vaccines for tropical theileriosis, babesiois and heart water: the continuing necessity. Trends in Parasitology. 23, pp. 420-426.

Shriwaikar, A., Prabhu, K.S. and Punitha, I.S.R. 2006. In vitro antioxidant studies on Sphaeranthus indicus Linn. Indian Journal of Experimental Biology, 44, pp. 993-996.

Singh, S.K., Saroj, K.M., Tripathi, V.J., Singh, A.K. and Singh, R.H. 1988. An antimicrobial principle from Sphaeranthus indicus L. (Family
Compositae). Pharmaceutical Biology, 26, pp. 235-239.

Snedecor, G.W. and Cochran, W.G. 1994. Statistical Methods ( $8^{\text {th }}$ Ed.). Iowa State University Press, Ames, Iowap. 491.

Srinivasan, D. and Nadarajan, L. 2006. Wet land weed Sphaeranthus indicus Asteraceae (Linn.) a potential green pesticide for managing angoumois grain moth Sitotroga cerealella (Oliv.). Resistant Pest Management Newsletter 16, pp. 21-25.

Sunil, A.R., Amithamol, K.K., Juliet, S., Nair, S.N., Ajithkumar, K.G., Soorya, V.C., Divya, T.M. Jyothimol, G., Ghosh, S. and Ravindran, R. 2013. Acaricidal effect of Cassia fistula Linn. Leaf ethanolic extract against Rhipicephalus (Boophilus) annulatus. Tropical Biomedicine, 30, pp. 231-237.

Tiwari, A. and Saxena, R.C. 2003. Repellent and feeding deterant activity of Sphaeranthus indicus against Tribolium castanum. Bio-Science Research Bulletin, 1, pp. 179-284.

Tiwari, B.K. and Khosa, R.L. 2009. Hepatoprotective and antioxidant effect of Sphaeranthus indicus against acetaminophen induced hepatotoxicity in rats. Journal of Pharmaceutical Sciences and Research, 1, pp. 26-30.

\section{How to cite this article:}

Thirumangalath Meethal Divya, Valliparampil Chandran Soorya, Krishnan Kavillimakkil Amithamol, Darsana Udayan, Kanapadinchareveetil Sreelekha, Suresh Narayanan Nair, Karaparrambil Gopalan Ajithkumar, Sanis Juliet, Reghu Ravindran and Srikant Ghosh. 2019. Acaricidal Activity of Crude Ethanolic Extract of Sphaeranthus indicus, Its Fractions and Subfractions against Rhipicephalus (Boophilus) annulatus (Acari: Ixodidae). Int.J.Curr.Microbiol.App.Sci. 8(08): 787-797. doi: https://doi.org/10.20546/ijcmas.2019.808.089 